\title{
Berardinelli-Seip syndrome in a Chinese boy with Seipin gene mutation: a case study and literature review of genotype-phenotype
}

\author{
Shan Huang ${ }^{1 *}$, Cai Zhang ${ }^{1}$, Yan Liang ${ }^{1}$, Qin Ning ${ }^{2}$, Xiao-Ping Luo ${ }^{1}$ \\ From 7th APPES Biennial Scientific Meeting \\ Nusa Dua, Bali. 14-17 November 2012
}

\section{Objective}

Congenital generalized lipodystrophy (CGL), or Berardinelli-Seip syndrome, is a rare and heterogeneous disease of autosomal recessive inheritance characterized by the generalized absence of adipose tissue at birth and severe adverse metabolic consequences. The identified causative genes for CGL include 1-acylglycerol-3-phosphate O-acyltransferase 2 (AGPAT2), Berardinelli-Seip congenital lipodystrophy 2 (BSCL2 or Seipin), Caveolin-1 (CAV1) and polymerase I and transcript release factor (PTRF). Although more than 60 cases of CGL with different gene mutations have been found in Asian patients, only 7 patients were Chinese. Data are also limited regarding genotype-phenotype analysis in Asian CGL patients. Therefore, we aimed to analyze variations of two identified major causative genes, Seipin and AGPAT2, involved in CGL etiology in a mainland Chinese affected family and explore the genotype-phenotype of Berardinelli-Seip syndrome in Asian populations.

\section{Methods}

We report a detailed clinical and genetic analysis of a Chinese boy with CGL who was followed from infancy through preschool. Sequences of the entire coding region of Seipin and AGPAT2 were examined. Phenotypes in various Asian subtypes were compared and the related literature about Berardinelli-Seip syndrome was reviewed.

\section{Results}

We identified a homozygous frameshift mutation (c.974975insG) in the Seipin gene in the CGL-affected boy.

'Department of Pediatrics, Tongji Hospital. Tongji Medical College of

Huazhong University of Science and Technology, Wuhan, China

Full list of author information is available at the end of the article
His parents were heterozygous for the same mutation. No variation was found in the AGPAT2 gene.

\section{Conclusion}

In Asian populations, Seipin and PTRF are the main genes identified to date as being responsible for CGL and Seipin is a major causative gene. Genetic heterogeneity is accompanied by phenotypic heterogeneity.

\section{Authors' details}

'Department of Pediatrics, Tongji Hospital. Tongji Medical College of Huazhong University of Science and Technology, Wuhan, China.

${ }^{2}$ Department of Infectious Diseases, Tongji Hospital. Tongji Medical College of Huazhong University of Science and Technology, Wuhan, China.

Published: 3 October 2013

doi:10.1186/1687-9856-2013-S1-P47

Cite this article as: Huang et al:: Berardinelli-Seip syndrome in a Chinese boy with Seipin gene mutation: a case study and literature review of genotype-phenotype. International Journal of Pediatric Endocrinology 2013 2013(Suppl 1):P47.

Submit your next manuscript to BioMed Central and take full advantage of:

- Convenient online submission

- Thorough peer review

- No space constraints or color figure charges

- Immediate publication on acceptance

- Inclusion in PubMed, CAS, Scopus and Google Scholar

- Research which is freely available for redistribution 